\title{
The Improved Method for Isolation of Photochrome Transmembrane Protein Bacteriorhodopsin from Purple Membranes of Halobacterium Halobacterium Halobium ET 1001
}

\author{
Oleg Mosin $^{1} \quad$ Ignat Ignatov $^{2 *}$ \\ 1. PhD (Chemistry), Biotechnology Department, Moscow State University of Applied Biotechnology, \\ Talalikhina Street, 33, Moscow 109316, Russian Federation \\ 2. DSc, Professor, Scientific Research Center of Medical Biophysics (SRCMB), \\ N. Kopernik Street, 32, Sofia 1111, Bulgaria
}

\begin{abstract}
We proposed the improved method for isolation of photochrome transmembrane protein bacteriorhodopsin (output $5 \mathrm{mg}$ from $100 \mathrm{~g}$ of wet biomass) capable to transform light energy to electrochemical energy of generated protons $\mathrm{H}^{+}$and ATP. The protein was isolated from purple membranes of photo-organotrophic halobacterium Halobacterium halobium ET 1001 by cellular autolysis by distilled water, processing of bacterial biomass by ultrasound at $22 \mathrm{KHz}$, alcohol extraction of low and high-weight molecular impurities, cellular RNA, carotenoids and lipids, solubilization with $0.5 \%$ (w/v) SDS-Na, fractionation by $\mathrm{MeOH}$ and column gel permeation chromatography (GPC) of the final protein on Sephadex G-200 with $0.1 \%$ (w/v) SDS-Na and 2.5 mM ETDA. The homogeneity of the isolated BR was proved by combination of preparative and analytical methods including electrophoresis in 12.5\% (w/v) PAAG with $0.1 \%(\mathrm{w} / \mathrm{v})$ SDS-Na and regeneration of apomembranes with 13-trans-retinal.
\end{abstract}

Keywords: Halobacterium halobium, purple membranes, bacteriorhodopsin, biosynthesis, biomolecular electronics

\section{Introduction}

Bacteriorhodopsin (BR), denoted by analogy to the visual apparatus of mammalian protein rhodopsin, was isolated from the cell membrane of extreme aerobic photo-organotrophic halobacterium Halobacterium halobium in 1971 by D. Osterhelt and W. Stohenius (Oesterhelt \& Stoeckenius, 1971). This photo-transforming integral trans-membrane protein with the molecular weight $\sim 26.5 \mathrm{kDa}$ represents chromoprotein determining the purple-red color of halophilic bacteria, which contains as chromophore group an equimolar mixture of 13-cisand 13-trans-retinol C20 carotenoid, bound by schiff base (as in the visual animal pigments) with Lys-216 residue of the protein. In halobacteria $\mathrm{BR}$ functions as a light-driven transmembrane proton pump pumping a proton accros the membrane. Along with the BR the cell membrane of halobacteria contains a small amount of other related carotenoid pigments, the main of which bakterioruberin determining the stability of halobacteria to solar radiation (Oesterhelt, 1988).

$\mathrm{BR}$ is the focus of bio-and nanotechnology mainly because of its high sensitivity and resolution, and is used in molecular bioelectronics as natural photochromic material for light-controlled electrical regulated computer modules and optical systems (Vought \& Birge, 1999; Hampp \& Oesterhelt, 2004). In addition, BR is very attractive as a model for studies of functional activity and structural properties of photo-transforming membrane proteins in the composition of native and photo-converting membranes (Mosin et al., 1994; Mosin et al., 1999).

BR-containing nano-films produced using the BR-containing purple membranes of halobacteria were first obtained and studied in this country in the framework of the project "Photochrome", when it was demonstrated effectiveness and prospects for the use of BR as photochromic material for holographic recording. These nanomaterials can reversibly change their structure in response to the physical impact and generate two discrete states, calculable by measurement with using spectral methods. This fact determines their usage as logical computing systems in bimolecular electronics (Hampp, 2000; Hillebrecht et al., 2005; Mohammadi, 2012). Thus, based on bacteriorhodopsin was constructed a photoreceptor with a microelectrode of $\mathrm{SnO}_{2}$, consisting of 64 cells (pixels) with the size of $2.5 \times 2.5 \mathrm{~mm}$ and electric voltage of $0.3-0.7 \mathrm{~V}$ (Gui-Ying et al., 2012). For the signal conversion by this photoreceptor, low electric current (3-10 nA) was enhanced to voltage from 1 to $10 \mathrm{~V}$ and then was supplied to the light emitting diodes. This construction suggests the possibility of effective integration of bacteriorhodopsin into modern microelectronic systems.

The main task for the manufacture of BR-containing nanofilms is the orientation of purple membranes between the hydrophobic and hydrophilic media, such as between water and air, as is common in nature. Typically, to improve the characteristics of the BR-containing films using multiple layers that are applied to the surface of the polymeric carrier and dried up, preserving their natural structure. The best results are achieved in the manufacture of films based on gelatin matrix (Shuguang et al., 1993; Wang et al., 2008). This allows for a 
high concentration of BR (up to 50\%) nanofilms to avoid aggregation magenta membrane fragments and destruction of bacteriorhodopsin in the manufacturing process (Weetall, 1996). Embedded onto a gelatin matrix purple membrane fragments are durable $\left(\sim 10^{4} \mathrm{~h}\right)$ and resistant to many external factors as temperature variations, intense light exposure, laser radiation, etc. (Downie et al., 1998). Dried purple membranes are stacked on the top of each other, focusing in the plane of the matrix. A layer of dried membrane with thickness of $\sim 1 \mu \mathrm{m}$ contains about 200 monolayers. When illuminated by light in such nanofilms is recorded the electric potential approximately 100-200 mV, which coincides with the membrane potential of living cells (Korposh et al., 2005). The structure and mechanism of BR have been widely studied in recent years to develop many various approaches of isolation of the protein in native biologically active state that requires the solubilization of BR in a stable, highly purified state free from native lipids (Mosin et al., 2012; Mosin et al., 2013). Large scientific and practical interest for obtaining BR samples for the reconstruction of the nanofilms, defined the aim of the present research, related to the development of simple effective method for isolation of BR from PM in semi-scale quantities.

\section{Material and Methods}

\subsection{Bacterial Strain}

As a BR producer was used a carotenoid strain of extreme photo-organotrophic halobacterium Halobacterium halobium ET 1001, obtained from Moscow State University (Russia). The strain was modified by selection to individual colonies on solid $2 \%(\mathrm{w} / \mathrm{v})$ agarose media with peptone and $4.3 \mathrm{M} \mathrm{NaCl}$.

\subsection{Chemicals}

For preparation of growth media were used $D, L$-amino acids ("Reanal", Hungary), AMP, UMP, biotin, folic acid and vitamin $B_{12}-2 \cdot 10^{-5}$ purchased from "Sigma Corp." (USA). Organic salts were obtained from P.L. Voikov plant of chemical reagents (Moscow, Russia). Buffer components were from Reachim-Pharm Ltd. (Russia). All solvents were of HPLC grade. Other chemical reagents were of analytical reagent grade. Filtrated water was provided by the Milli-Q-Plus water filtration system (Millipore, Bedford, MA, USA).

\subsection{Growth Conditions}

The bacterial growth was carried out on synthetic medium (SM) containing (g/l): $D, L$-alanine $-0.43 ; L$-arginine - 0.4; $D, L$-aspartic acid $-0.45 ; L$-cysteine $-0.05 ; L$-glutamic acid $-1.3 ; L$-lycine $-0.06 ; D, L$-histidine -0.3 ; $D, L$-isoleucine $-0.44 ; L$-leucine $-0.8 ; L$-lysine $-0.85 ; D, L$-methionine $-0.37 ; D, L$-phenylalanine $-0.26 ; L$ proline - $0.05 ; D, L$-serine - $0.61 ; D, L$-threonine - $0.5 ; L$-tyrosine - $0.2 ; D, L$-tryptophan - $0.5 ; D, L$-valine - 1.0 , AMP - 0.1; UMP - 0.1; NaCl - 250; $\mathrm{MgSO}_{4} 7 \mathrm{H}_{2} \mathrm{O}-20 ; \mathrm{KCl}-2 ; \mathrm{NH}_{4} \mathrm{Cl}-0.5 ; \mathrm{KNO}_{3}-0.1 ; \mathrm{KH}_{2} \mathrm{PO}_{4}-0.05$; $\mathrm{K}_{2} \mathrm{HPO}_{4}-0.05 ; \mathrm{Na}^{+}$-citrate $-0.5 ; \mathrm{MnSO}_{4} 2 \mathrm{H}_{2} \mathrm{O}-3 \cdot 10^{-4} ; \mathrm{CaCl}_{2} \cdot 6 \mathrm{H}_{2} \mathrm{O}-0.065 ; \mathrm{ZnSO}_{4} 7 \mathrm{H}_{2} \mathrm{O}-4 \cdot 10^{-5}$; $\mathrm{FeSO}_{4} 7 \mathrm{H}_{2} \mathrm{O}-5 \cdot 10^{-4} ; \mathrm{CuSO}_{4} \cdot 5 \mathrm{H}_{2} \mathrm{O}-5 \cdot 10^{-5}$; Na-citrate -0.5 ; glycerol -1.0 , biotin $-1 \cdot 10^{-4}$; folic acid $-1.5 \cdot 10^{-4}$, vitamin $\mathrm{B}_{12}-2 \cdot 10^{-5}$. The growth medium was autoclaved for $30 \mathrm{~min}$ at $0.5 \mathrm{~atm}$, the $\mathrm{pH}$ value was adjusted to 6.5-6.7 with $0.5 \mathrm{M} \mathrm{KOH}$. Bacterial growth was performed in $500 \mathrm{ml}$ Erlenmeyer flasks (volume of the reaction mixture $100 \mathrm{ml}$ ) for $4-5$ days at $35{ }^{\circ} \mathrm{C}$ on a shaker ("Birad Labs", Hungary) under intense aeration and monochromatic illumination by light fluorescent lamps LDS-40-2 (40 W) (“Alfa-Electro", Russia ) (3 lamps $\times$ $1.5 \mathrm{~lx}$ ). Bacterial growth was studied by optical density of the bacterial suspension measured at a wavelength $\lambda=$ $620 \mathrm{~nm}$ on a spectrophotometer Beckman DU-6 ("Beckman Coulter", USA). All further manipulations with BR were carried out with the use of a photomask lamp equipped with an orange light filter PCM $-1 X(75 \times 50 \mathrm{~cm})$ ("Marbel", Germany).

\subsection{Isolation of Purple Membranes (PM)}

Row biomass $(1 \mathrm{~g})$ was washed with distilled water and pelleted by centrifugation on T-24 centrifuge ("Carl Zeiss", Germany) (1500 g, $20 \mathrm{~min}$ ). The precipitate was suspended in $100 \mathrm{ml}$ of dist. $\mathrm{H}_{2} \mathrm{O}$ and kept for $\sim 3 \mathrm{~h}$ at 4 ${ }^{0} \mathrm{C}$. The reaction mixture was centrifuged $(1500 \mathrm{~g}, 15 \mathrm{~min})$, the pellet was resuspended in $20 \mathrm{ml}$ dist. $\mathrm{H}_{2} \mathrm{O}$ and disintegrated by infrasound sonication $(22 \mathrm{kHz}, 1 \mathrm{~min})$ in an ice bath $\left(0{ }^{0} \mathrm{C}\right)$. The cell homogenate after washing with dist. $\mathrm{H}_{2} \mathrm{O}$ was resuspended in $10 \mathrm{ml}$ of buffer containing $125 \mathrm{mM} \mathrm{NaCl}, 20 \mathrm{mM} \mathrm{MgCl}$, and $4 \mathrm{mM}$ Tris$\mathrm{HCl}(\mathrm{pH}=8.0)$, then $5 \mathrm{mg}$ of RNA-ase (2-3 units of activity) was added. The mixture was incubated in the dark for $\sim 2 \mathrm{~h}$ at $37{ }^{\circ} \mathrm{C}$. Then $10 \mathrm{ml}$ of the same buffer was added and kept for $10-12 \mathrm{~h}$ at $4{ }^{0} \mathrm{C}$. The aqueous fraction was separated by centrifugation on T-24 centrifuge ("Carl Zeiss", Germany) (1500 g, 20 min), the PM precipitate was treated with $50 \%(\mathrm{v} / \mathrm{v}) \mathrm{EtOH}(5$ times $\times 5 \mathrm{ml})$ at $4{ }^{0} \mathrm{C}$ followed by separation of the solvent. This procedure was repeated 5 times to give a colorless washings. The protein content in the samples was determined spectrophotometrically on a Beckman DU-6 spectrophotometer ("Beckman Coulter", USA) by the ratio $\mathrm{D}_{280} / \mathrm{D}_{568}\left(\varepsilon_{280}=1.1 \cdot 10^{5} \mathrm{M}^{-1} \mathrm{~cm}^{-1} ; \varepsilon_{568}=6.3 \cdot 10^{4} \mathrm{M}^{-1} \mathrm{~cm}^{-1}\right)$ (Neugebauer et al., 1978). Regeneration of PM was performed as described in (Rudiger et al., 1997). The output of PM fraction, $120 \mathrm{mg}$ (80-85\%). 


\subsection{Isolation of $B R$}

Fraction of PM (in $\left.\mathrm{H}_{2} \mathrm{O}\right)(1 \mathrm{mg} / \mathrm{ml})$ was dissolved in $10 \mathrm{ml}$ of $0.5 \%(\mathrm{w} / \mathrm{v})$ SDS-Na, and incubated for $\sim 5-7 \mathrm{~h}$ at $37{ }^{\circ} \mathrm{C}$ followed by centrifugation $(1200 \mathrm{~g}, 15 \mathrm{~min})$. The precipitate was separated, than $\mathrm{MeOH}$ was added to the supernatant in divided portions $\left(3\right.$ times $\times 2 \mathrm{ml}$ ) at $0{ }^{0} \mathrm{C}$. The reaction mixture was kept for $\sim 14-15 \mathrm{~h}$ in ice bath at $4{ }^{\circ} \mathrm{C}$ and then centrifuged $(1200 \mathrm{~g}, 15 \mathrm{~min})$. Fractionation procedure was performed three times, reducing the concentration of $0.5 \%$ SDS-Na to 0.2 and $0.1 \%(w / v)$. Crystal protein (output, 8-10 mg) was washed with cold distilled. ${ }^{2} \mathrm{H}_{2} \mathrm{O}(2$ times $\times 1 \mathrm{ml})$ and centrifuged (1200 g, $\left.15 \mathrm{~min}\right)$.

\subsection{Purification of $B R$}

Protein sample $(5 \mathrm{mg}$ ) was dissolved in $10 \mathrm{ml}$ of buffer solution and placed on a calibrated chromatography column $(150 \times 10 \mathrm{~mm})$ with stationary phase - Sephadex G-200 ("Pharmasia", USA) (specific volume packed beads - 30-40 units per $1 \mathrm{~g}$ dry Sephadex), and equilibrated with buffer containing $0.1 \%$ (w/v) SDS-Na and 2.5 mM ETD. The device was equiped with Waters 2487 dual absorbance (UV/VIS) detector with the wavelength range at $\lambda=190-700 \mathrm{~nm}$. Elution proceeded by $1 \mathrm{mM}$ Tris- $\mathrm{HCl}$ buffer, $\mathrm{pH}=7.4$ at a flow rate $10 \mathrm{ml} / \mathrm{cm}^{2} \mathrm{~h}$. Combined protein fraction was subjected to freeze-drying, sealed in glass ampoules $(10 \times 50 \mathrm{~mm})$ and stored in frost camera at $-10{ }^{0} \mathrm{C}$.

\subsection{Electrophoresis of BR}

The procedure was performed in $12.5 \%$ (w/v) polyacrylamide gel (PAAG) containing 0.1\% (w/v) SDS. The samples were prepared for electrophoresis by standard procedures (LKB protocol, Sweden). Electrophoretic gel stained with Coomassie blue R-250 was scanned on a CDS-200 laser densitometer ("Beckman", USA) for quantitative analysis of the protein level.

\subsection{Proton Translocation}

Proton translocation was recorded in visicles with a gel-filled pH relectrode (Sensorex No. SG900C) combined with PHM85 Radiometer $\mathrm{pH}$ meter. The data were collected $(0.8 \mathrm{~s}$ per time interval) and analysed using Lotus Measure (Lotus Development). Initial proton pumping rates were determined over $10 \mathrm{~s}$ interval. Changes in $\mathrm{pH}$ were calibrated using $1 \mu \mathrm{m}$ of $10 \mathrm{mM} \mathrm{HCl}$.

\subsection{Preparation of Apomembranes (AP)}

$50 \mathrm{mg}$ of $\mathrm{PM}$ was suspended in $50 \mathrm{ml}$ of $1 \mathrm{M} \mathrm{NH}_{2} \mathrm{OH}(\mathrm{pH}=6.0)$. The reaxion mixure was kept for $10 \mathrm{~h}$ with stirring in ice bath $\left(4{ }^{0} \mathrm{C}\right)$ under illumination with a xenon lamp. The precipitate was separated by centrifugation $(1000 \mathrm{~g}, 10 \mathrm{~min})$, washed twice with distilled water and centrifuged. AP fraction was resuspended in $2 \mathrm{ml}$ of 5 $\mathrm{mM}$ 2-(N-morpholino)-ethane sulfonyl amide in $100 \mathrm{mM} \mathrm{NaCl}$.

\subsection{Regeneration of AP with 13-trans-retinal}

To $2 \mathrm{ml}$ suspension of AP $\left(2 \cdot 10^{-5} \mathrm{~mol}\right)$ in a quartz cuvette was added with stirring $0.1 \mathrm{ml}$ of $2 \mathrm{mM}$ solution of 13 trans-retinal in methanol and kept for $6-8 \mathrm{~h}$ in the dark at $40{ }^{0} \mathrm{C}$. The degree of regeneration of PM was determined by spectrophotometry on CDS-200 laser densitometer ("Beckman", USA) by the ratio: $D_{\text {nat.280 }} \cdot D_{\text {nat..568 }} / D_{\text {reg. } .280} D_{\text {reg.568, }}$, where $D_{280}$ and $D_{568}$ - the absorbance of a suspension of native and regenerated $\mathrm{PM}$ at $\lambda=280$ and $\lambda=568 \mathrm{~nm}$.

\section{Results and Discussion}

\subsection{Structure and Mechanism of Action of BR}

On its structure and location in the cell membrane BR refers to integral transmembrane proteins (Fig. 1), penetrating the cell membrane, which is divided into three separate fractions: yellow, red and purple. Purple fraction comprising $75 \%(\mathrm{w} / \mathrm{w})$ of cell membrane consists from carotenoids, phospholipids (mostly phosphoglycerol diesters of phosphatidyl glycerol phosphate (PGP) with a small amount of nonpolar lipids and isoprenoids) forms a natural two-dimensional crystals which can be investigated using electron microscopy diffraction methods as X-ray scattering (Lanyi, 2004). These methods have established the existence in the BR molecule of seven $\alpha$-helical protein segments which span the lipid matrix, while in the middle part is symmetrically located a retinal residue being covalently linked to Lys-216 residue in the G helix so that that each protein molecule has one retinal moiety (vitamin A base) (Fig. 1). In the native membrane the polypeptide chain is oriented with the amino-end $\mathrm{N}$-terminal in the extracellular medium and the carboxyl $\mathrm{C}$-terminal inside the cytoplasmic side. The carboxyl C-terminal is non-helical consists of 24 amino acid residues, four of them are negatively charged and two positevely charged. Other chains connecting the helixes on the cytoplasmic side contain a total of five additional negatively charged residues but no more positevely charged residues. The amino-end N-terminal of the protein is also nonhelical and consists of six residues. 


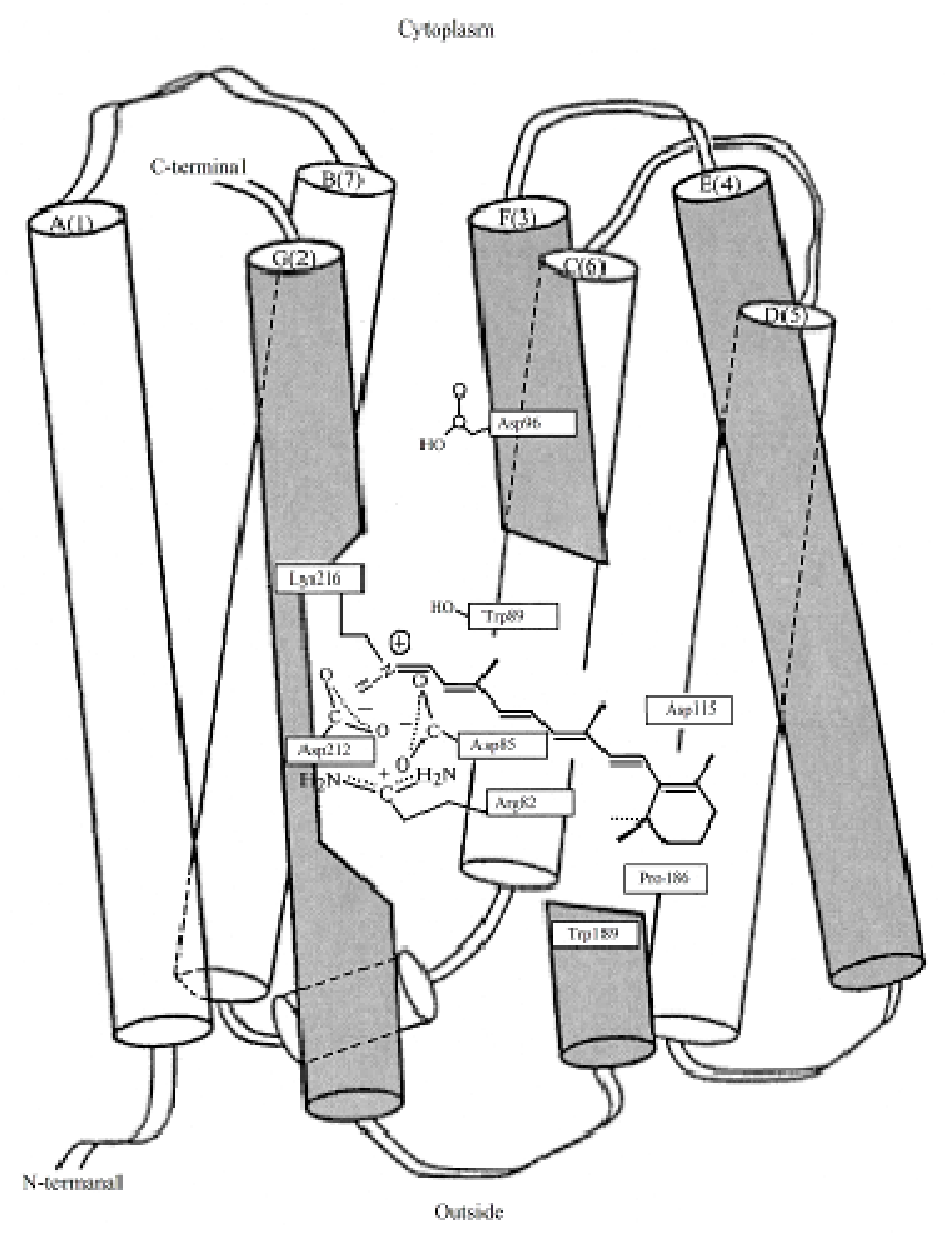

Figure 1: The location of protein and retinal residue in the BR molecule of halobacteria $H$. halobium according to computer modeling: Latin numerals indicate protein fragments of BR molecule as $7 \alpha$-helical segments (A, B, C, D, E, G, F) with exposed amino acid residues; gray color represents the segments responsible for binding of retinal residue to the $\mathrm{G}$-helical segment of $\mathrm{BR}$ molecule.

Polypeptide chain of BR consists of 248 amino acid residues, 67\% of which are hydrophobic, formed with the aromatic amino acids, and 33\% - hydrophilic residues of aspartic and glutamic acids, arginine and lysine; the protein does not contain histidine or cyctein (Jap et al., 1983). These residues play important structural and functional role in the spatial orientation of the $\alpha$-helical segments of the BR molecule, arranged in $\mathrm{PM}$ in an orderly manner forming trimmers with an average diameter $\sim 0.5 \mu \mathrm{m}$ and a thickness $5-6 \mathrm{~nm}$; each trimmer is surrounded by six others so that to form a regular hexagonal lattice (Mak-Jurkauskas et al., 2008). The BR molecule consists of seven $\alpha$-helix segments, arranged in a direction perpendicular to the plane of the membrane (Figure 2). Hydrophobic domains representing transmembrane segments and hydrophilic domains protruding from the membrane connect the individual $\alpha$-helical intramembranous protein segments of the BR molecules. Along with BR the PM contain lipids, carotenoids and water in their composition. 

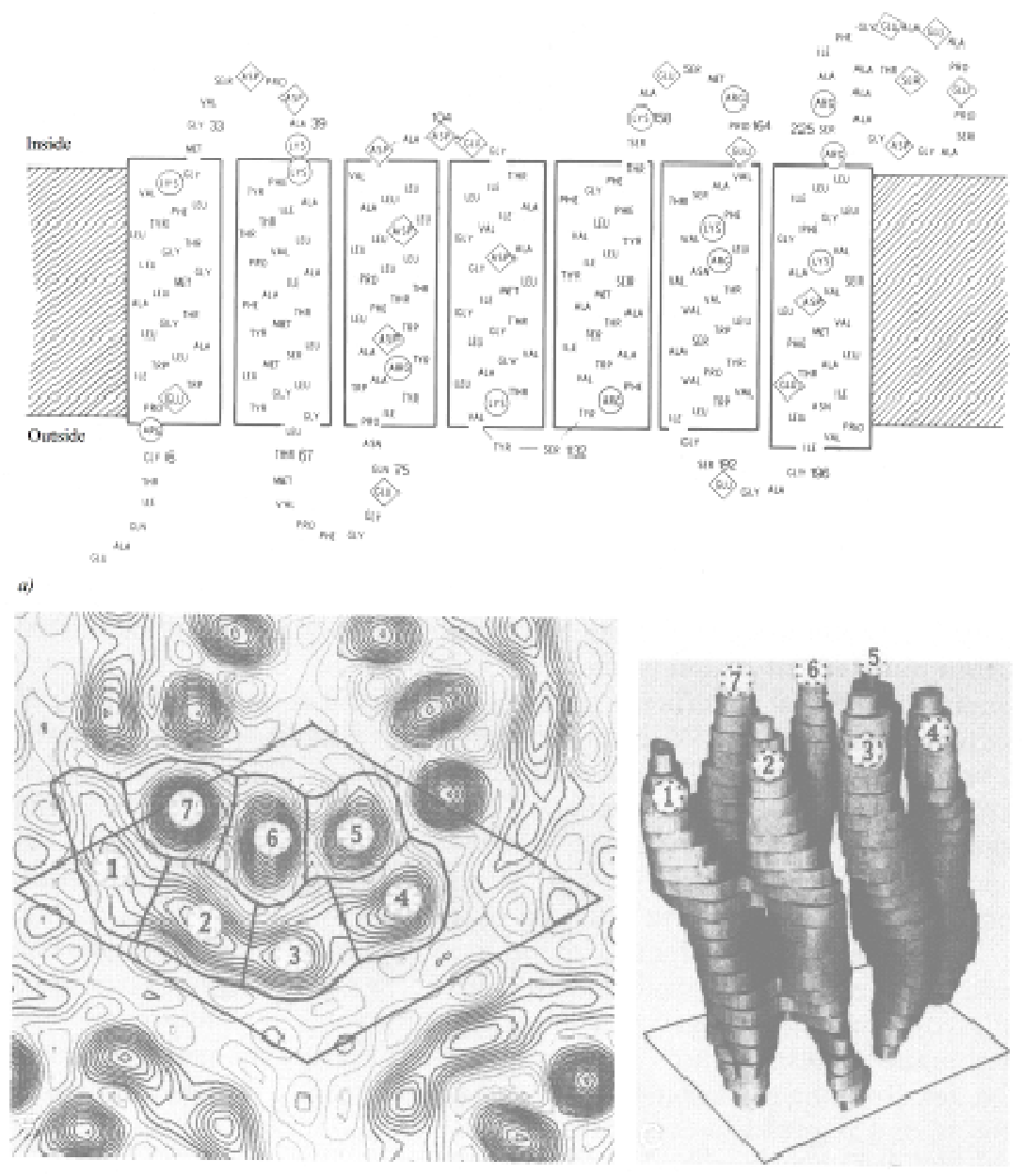

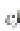

Figure 2: The structure of the BR molecule according to diffraction analysis:

a) - the primary structure of the BR molecule: amino acids indicated in Latin characters, circles and rhombs show the functionally important amino acids responsible for spatial orientation of $\alpha$-helical segments of the protein moiety of the BR molecule and the formation of channels for the transfer of protons $\mathrm{H}^{+}$across the cell membrane;

b) - electron density map of PM (a single molecule of the protein is encircled in the center). Numbers 1-7 are designated $\alpha$-helical segments of the BR molecule: - 1-A-segment; 2 -B-segment; 3 - C-segment; 4 - D-segment; 5 - E-segment; 6 - F-segment; 7 - G-segment;

c) - the spatial structure of the BR molecule: 1 - A-segment; 2 - B-segment; 3 - C-segment; 4 - Dsegment; 5 - E-segment; 6 - F-segment; 7 - G-segment.

Owing to its unique structure, BR molecule acts as a light-dependent proton pump, pumping protons across the cell membrane and generates an electrochemical gradient of $\mathrm{H}^{+}$on the surface of the cell membrane, which energy is used by the cell for the synthesis of ATP in the anaerobic photosynthetic phosphorylation. The mechanism of ATP synthesis is denoted as "non-chlorophyll photosynthesis", in contrast to the plant photosynthesis implemented with the participation of chlorophyll. In this mechanism, at absorbtion of a light photon BR molecule became decolorized by entering into the cycle of photochemical reactions, resulting in the release of a proton to the outside of the membrane, and the absorption of a proton from intracellular space. By the absorption of a light photon is occurred a reversible isomerization of all 13-tras-BR $\left(\lambda_{\max }=548 \mathrm{~nm}\right)($ the quantum yield 0.03 at $\left.20{ }^{\circ} \mathrm{C}\right)$ into the 13 -cis-BR $\left[\left(\lambda_{\max }=568 \mathrm{~nm}\right)\right.$ (Haupts, 1997)], initiating a cascade of photochemical reactions lasting from $3 \mathrm{~ms}$ to $1 \mathrm{ps}$ with the formation of transitional intermediates $J, K, L, M, N$, and $\mathrm{O}$, followed by separation of $\mathrm{H}^{+}$from the retinal residue of $\mathrm{BR}$ and its connection from the side of cytoplasm, and finally returns to its 13-trans-conformation while remaining bonded to the protein throughout the photo-cycle (Fig. 3). In this process a proton originating at the schiff base of the retinal residue is passed across by being transferred to the hydrophilic Asp-85 residue lying in sterically favorable positions, to the other side of the cellular membrane; right after that the vacancy is filled up with a proton transferred from Asp-96 residue 
(Zimanyi et al., 1993). As a result, between the internal and external surface of the membrane forms a concentration gradient of $\mathrm{H}^{+}$, resulting that illuminated by light halobacteria cells begin to synthesize ATP, i.e. convert light energy into the energy of chemical bonds. This process is reversible and in the dark flows back in the opposite direction, allowing to halobacteria developing in the dark by means of switching of photosynthetic metabolism to the heterotrophic metabolism. Thus, the BR molecule behaves as a photochromic carrier with a short relaxation time - the transition from the excited state to the ground state. Optical characteristics of BR vary depending on the method of preparation of PM and the properties of embedded polymer matrix.

$\mathrm{PM}$ are resistant to solar light, the effects of oxygen, temperatures greater than $80{ }^{\circ} \mathrm{C}$ (in water) and up to $+140{ }^{0} \mathrm{C}$ (in air), $\mathrm{pH}=1-12$, a high concentration of $\mathrm{NaCl}(15-20 \%(\mathrm{w} / \mathrm{w}))$ and action of most proteases (Seitz \& Hampp, 2000; Shamansky et al., 2002). Additionally, PM resistant to nonpolar solvents such as hexane, but sensitive to mixtures of polar organic solvents with water. These factors are of great practical importance for integration of PM into polymeric nanomatrix with keeping photochemical properties.

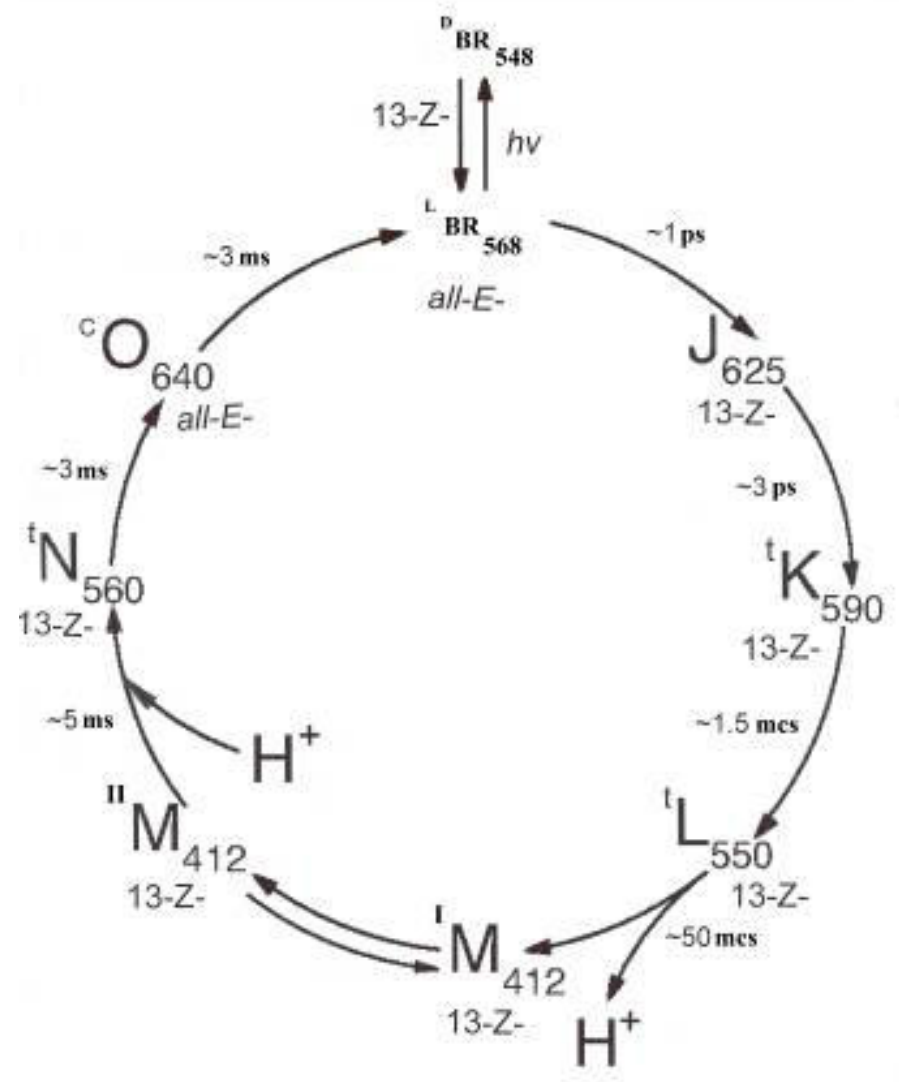

Figure 3: Photocycle scheme of BR (aqueous solution, $\mathrm{pH}=7.2 ; \mathrm{t}=20{ }^{\circ} \mathrm{C}$ ). Latin numbers $\mathrm{J}, \mathrm{K}, \mathrm{L}, \mathrm{M}, \mathrm{N}, \mathrm{O}$ denote spectral intermediates of BR. ${ }^{\mathrm{I}} \mathrm{M}$ and ${ }^{\mathrm{II}} \mathrm{M}$ represent spectral intermediants of meta-bacteriorhodopsin with the protonated $\left({ }^{\mathrm{I}} \mathrm{M}\right)$ and deprotonated $\left({ }^{\mathrm{II}} \mathrm{M}\right)$ aldimine bond. $\mathrm{L}$ and $\mathrm{D}$ denote dark and light forms of pigments. The subscripts correspond to the position of the absorption maximum in the photocycle intermediates $(\mathrm{nm})$

\subsection{Biosynthesis of $B R$}

Technology for preparation of BR consists in growing of halobacteria on liquid synthetic growth media (with 15-20\% (w/w) $\mathrm{NaCl}$ ) with amino acids, or on natural growth media with peptons - mixtures of polypeptides and amino acids derived from the partial hydrolysis product or powdered milk, animal meat by proteolytic enzymes (pepsin, trypsin, chymotrypsin), or protein- vitamin concentrate of yeast. The subsequent isolation of BR from purple membranes is carried out by a combination of physical and chemical methods.

For synthesis of BR was used the carotenoid-containing mutant strain of extreme photo-organotrophic halobacterium $H$. halobium. The initial strain was modified by selection of BR synthesizing individual colonies of purplish red color on the solid ( $2 \%$ agarose) growth medium with peptone and $4.3 \mathrm{M} \mathrm{NaCl}$.

For biosynthesis of BR the resulting cells were grown aerobically under monochromatic light illumination on a specifically desined SM-medium containing (g/l):

- 18 amino acids: $D, L$-alanine $-0.43 ; L$-arginine $-0.4 ; D, L$-aspartic acid $-0.45 ; L$-cysteine $-0.05 ; L$ glutamic acid - $1.3 ; L$-lycine $-0.06 ; D, L$-histidine $-0.3 ; D, L$-isoleucine $-0.44 ; L$-leucine $-0.8 ; L$-lysine -0.85 ; $D, L$-methionine $-0.37 ; D, L$-phenylalanine $-0.26 ; L$-proline $-0.05 ; D, L$-serine $-0.61 ; D, L$-threonine $-0.5 ; L$ - 
tyrosine $-0.2 ; D, L$-tryptophan $-0.5 ; D, L$-valine -1.0 ;

- Nucleotides: adenosine-5-monophosphate - 0.1; uridine-5-monophosphate - 0.1;

- Inorganic salts: $\mathrm{NaCl}-250 ; \mathrm{MgSO}_{4} 7 \mathrm{H}_{2} \mathrm{O}-20 ; \mathrm{KCl}-2 ; \mathrm{NH}_{4} \mathrm{Cl}-0.5 ; \mathrm{KNO}_{3}-0.1 ; \mathrm{KH}_{2} \mathrm{PO}_{4}-0.05$; $\mathrm{K}_{2} \mathrm{HPO}_{4}-0.05 ; \mathrm{Na}^{+}$-citrate $-0.5 ; \mathrm{MnSO}_{4} \cdot 2 \mathrm{H}_{2} \mathrm{O}-3 \cdot 10^{-4} ; \mathrm{CaCl}_{2} \cdot 6 \mathrm{H}_{2} \mathrm{O}-0.065 ; \mathrm{ZnSO}_{4} \cdot 7 \mathrm{H}_{2} \mathrm{O}-4 \cdot 10^{-5}$; $\mathrm{FeSO}_{4} \cdot 7 \mathrm{H}_{2} \mathrm{O}-5 \cdot 10^{-4} ; \mathrm{CuSO}_{4} \cdot 5 \mathrm{H}_{2} \mathrm{O}-5 \cdot 10^{-5}$;

- Glycerol - 1.0;

- Na-citrate - 0.5;

- Growth factors: biotin $-1 \cdot 10^{-4}$; folic acid $-1.5 \cdot 10^{-4}$, vitamin $\mathrm{B}_{12}-2 \cdot 10^{-5}$.

In accordance to the daily measurements of optical density of cell suspension were plotted curves of bacterial growth of $H$. halobium on SM-medium shown in Fig. $4 \mathrm{~b}$ relative to the control (Fig. $4 a$ ) on peptone medium. In these experimental conditions, cells synthesize the purple carotenoid pigment, identified as a natural BR by the spectral ratio of protein and chromophore molecule fragments $-\mathrm{D}_{280} / \mathrm{D}_{568}=1.5: 1.0$. The growth of halobacteria H. halobium on SM-medium (Fig. 4b) was insignificantly inhibited compared to the control (Fig. 4a) on the peptone medium that significantly simplifies and reduces the cost of biosynthesis of BR. The process consists in growing of halobacteria on SM-medium under illumination by light fluorescent lamps LDS-40-2 (40 W) with monochromatic light with $\lambda=560 \mathrm{~nm}$ for $4-5$ days at $35{ }^{\circ} \mathrm{C}$. A significant advantage of this is that unlike peptone medium, SM-medium does not contain protein contaminants that can complicate the subsequent isolation and purification of BR. All further manipulations with BR were carried out either in the dark or with using of a photomask lamp equipped with an orange light filter.

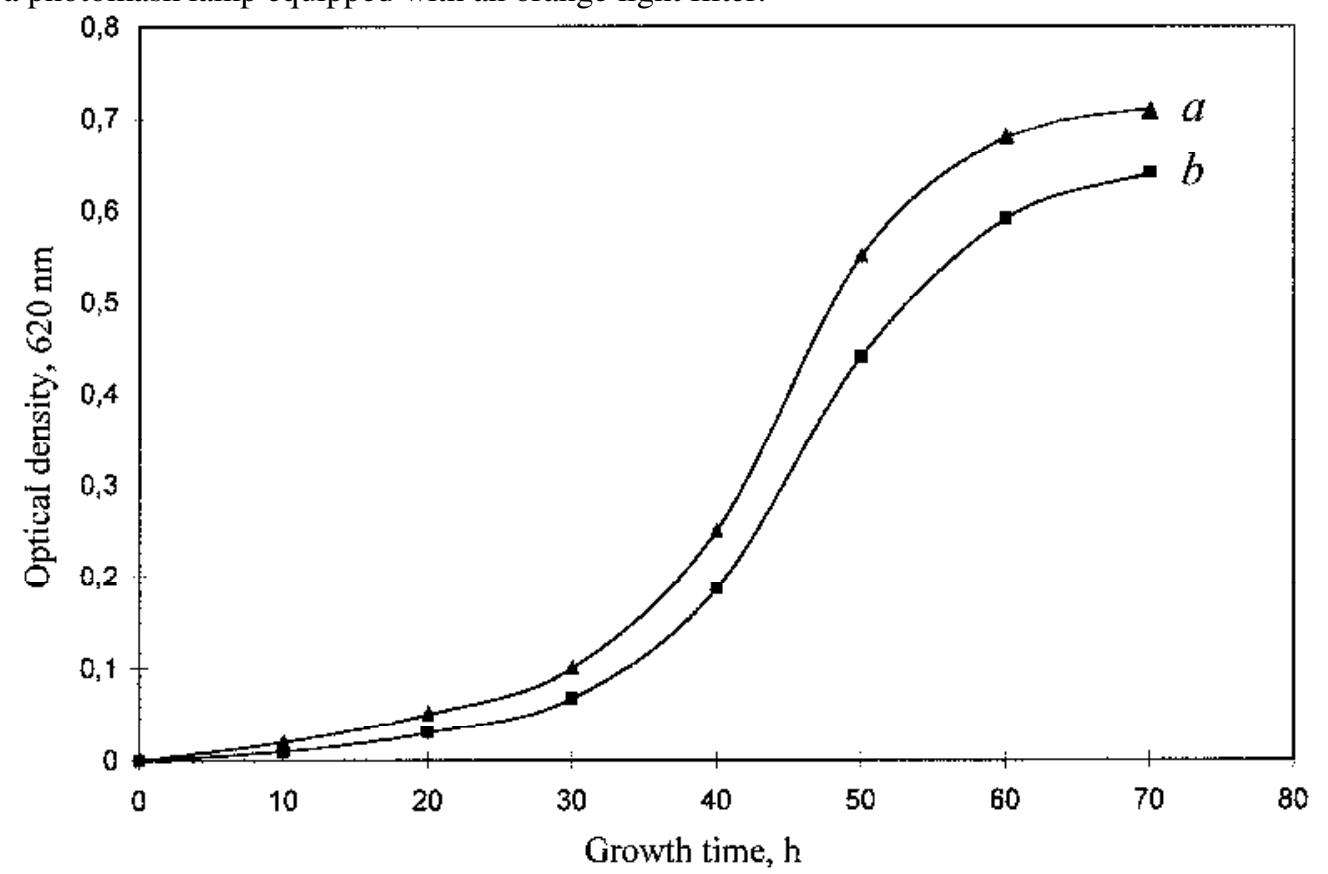

Figure 4: Growth dynamics of H. halobium under various experimental conditions: $a$ ) - SM-medium; $b$ ) peptone medium. Growing conditions: the incubation period: $4-5$ days, temperature: $35{ }^{0} \mathrm{C}$, illumination under monochrome light at $\lambda=560 \mathrm{~nm}$

\subsection{Isolation and Purification of $B R$}

The main stages of isolation of BR were:

- Growth of halobacteria H. halobium on SM-medium;

- Cell disintegration and autolysis;

- Separation of purple membrane (PM) fraction;

- Purification of PM from the low and high-molecular weight impurities, cellular RNA, carotenoids and phospholipids;

- Solubilization of PM in $0.5 \%$ (w/v) solution of ionic detergent SDS-Na to form a micro-emulsion;

- Fractionation of the solubilized BR by $\mathrm{MeOH}$;

- Gel permeation chromatography (GPC) on Sephadex G-200;

- Electrophoresis in $12.5 \%$ (w/v) PAAG in $0.1 \%(\mathrm{w} / \mathrm{v}) \mathrm{SDS}-\mathrm{Na}$.

Since the protein is localized in PM, the release of low molecular weight impurities and intracellular contents was reached by osmotic shock of cells with distilled water in the cold after the removal of $4.3 \mathrm{M} \mathrm{NaCl}$ and the 
subsequent destruction of the cell membrane by ultrasound at $22 \mathrm{kHz}$. For the destruction of cellular RNA the cellular homogenate was treated with RNase I. The resulted fraction of PM along with the desired protein in a complex with lipids and polysaccharides contained impurity of related carotenoids and proteins. Therefore, it was necessary to use special methods of fractionation of the protein without damaging its native structure and dissociation of retinal residue. That required applying the special methods for purification of carotenoids and lipids, and the subsequent gel permeation column chromatography (GPCC) on Sephadex G-200.

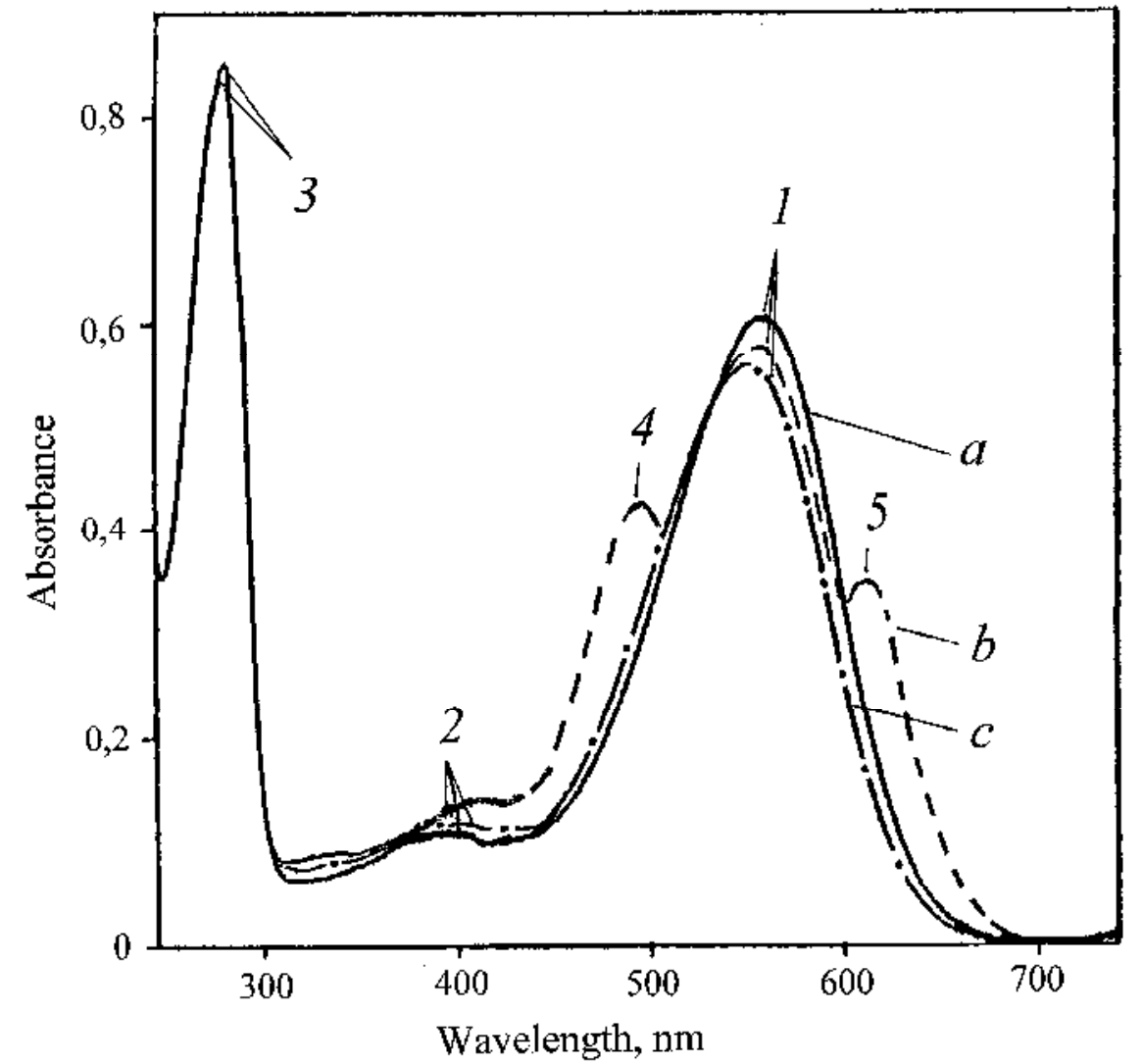

Figure 5: The absorption spectra of PM $(50 \%(\mathrm{v} / \mathrm{v})$ EtOH) at various stages of processing: $(a)$ - natural BR; $(b)-$ PM after intermediate treatment; $(c)$ - PM purified from carotenoids. The bandwith (1) is the spectral form of $\mathrm{BR}_{568}$, (2) - impurity of spectral form of meta-bacteriorhodopsin $\mathrm{M}_{412}$, (3) - the total absorption bandwith of aromatic amino acids, (4) and (5) - extraneous carotenoids. The native BR was used as a control.

In an attempt to remove a large fraction of the carotenoids and phospholipids from the membrane by column GPC, PM fraction was washed by $50 \%$ (v/v) of EtOH before stabilization by SDS-Na. Removing of carotenoids, consisting in repeated treatment of $\mathrm{PM}$ with $50 \%(\mathrm{v} / \mathrm{v}) \mathrm{EtOH}$ at $0{ }^{0} \mathrm{C}$, was a routine but necessary step, in spite of the significant loss of the chromoprotein. It was used five treatments by $50 \%(\mathrm{v} / \mathrm{v}) \mathrm{EtOH}$ to obtain the absorption spectrum of PM suspension purified from carotenoids (4) and (5) (degree of chromatographic purity of 80-85\%), as shown in Figure 5 at various processing stages $(b)$ and $(c)$ relative to the native BR (Fig. $5 a$ ). Figure 5 shows a dark-adapted absorption maximum at $\lambda=548 \mathrm{~nm}$. Formation of retinalprotein complex in the BR molecule leads to a bathochromic shift in the absorption spectrum of PM (Fig. 5c) the main bandwith (1) with the absorption maximum at $\lambda=568 \mathrm{~nm}$ caused by the light isomerization of the chromophore by the $\mathrm{C} 13=\mathrm{C} 14$ bond is determined by the presence of 13-trans-retinal residue in $\mathrm{BR}_{568}$; additional low-intensity bandwith (2) at $\lambda=412 \mathrm{~nm}$ characterizes a minor impurity of a spectral form of metabacteriorhodopsin $\mathrm{M}_{412}$ (formed in the light) with deprotonated aldimine bond between 13-trans-retinal residue and protein; the total bandwith (3) with $\lambda=280 \mathrm{~nm}$ is determined by the absorption of aromatic amino acids in the polypeptide chain of the protein (for native $B R D_{280} / \mathrm{D}_{568}=1.5: 1.0$ ). Upon light absorption, the maximum absorbance of PM shifts to $556 \mathrm{~nm}$ with $6-8 \%$ increase in extinction. The $280 / 568 \mathrm{~nm}$ absorbance ratio for BR is directly related to the ratio of total protein (the native BR) and is a convenient indicator for BR stability and integrity. Identical absorbance ratios are monitored using the conventional optics on a Beckman DU-6 spectrophotometer ("Beckman Coulter", USA) for detergent-solubilized BR or purified BR-solubilized in detergent.

The fractionation and chromatographic purification of the protein was a necessary next step of BR purification. For obtaining protein from a biological material in purified, homogeneous state using various 
detergents assisted to the cleavage of protein-lipid complexes and the rupture of protein-protein bonds. In particular, for the release of proteins (enzymes) which are firmly connected with biomembranes or other subcellular structures are Triton X-100, sodium dodecyl sulfate (SDS) and sodium deoxycholate.

As BR, being an integral membrane protein intricately penetrates bilipid layer in form of seven $\alpha$ helices, the use of ammonium sulfate and other conventional agents to salting out did not give a positive result for isolation of the protein. The resolving was in the translation of the protein to a soluble form by the colloidal dissolution (solubilization) in ionic detergent. Using as the ionic detergent SDS-Na was dictated by the need of carrying out more accomplished solubilization of the protein in a native, biologically active form in complex with 13-trans-retinal, because BR solubilized in $0.5 \%(\mathrm{w} / \mathrm{v})$ SDS-Na retains a native $\alpha$-helical configuration (Mosin et al., 1996). However SDS-Na is a strong detergent and its usage for protein fractionation is justified by a limited range of concentration (from 0.1 to $0.5 \%(\mathrm{w} / \mathrm{v})$ ). In addition SDS-Na seems to be more effective for lipid removal that other conventional detergents. Therefore, there was no need the use organic solvents as acetone, methanol and chloroform for purification of phospholipids, while precipitation and delipidization stages were being combined in one single step, which significantly simplifies the further fractionation of the protein and reduces its losses during precipitation procedure. A significant advantage of this method is that the isolated protein in complex with phospholipids and detergent was distributed in the supernatant, while other high molecular weight impurities - in the precipitate, which can be easily separated by centrifugation. Fractionation of solubilized in $0.5 \%(\mathrm{w} / \mathrm{v})$ SDS-Na protein and its subsequent isolation in crystalline form was performed at 0 ${ }^{0} \mathrm{C}$ in three steps precipitating procedure with $\mathrm{MeOH}$, slowly reducing the concentration of SDS-Na from 0.5 , 0.25 and $0.1 \%(\mathrm{w} / \mathrm{v})$. The final stage of BR purification involved the separation of the protein from lowmolecular-weight impurities by GPC. For this purpose the fractions containing BR were passed twice through a chromatography column with dextran Sephadex G-200 balanced with buffer $(\mathrm{pH}=8.35)$ containing $0.1 \%(\mathrm{w} / \mathrm{v})$ SDS-Na and $2.5 \mathrm{mM}$ EDTA. The data on purification of BR are shown in Table 1.

Table 1: The data on purification stafes of BR

\begin{tabular}{|l|l|l|l|}
\hline Sample & mol PM/mol BR & Phospholipid removal, \% & BR yield*, \% \\
\hline PM & 15.5 & - & - \\
\hline PM washed with EtOH & \multicolumn{2}{l|}{} \\
\hline 1 wash & 4.9 & 65 & 93 \\
\hline 2 wash & 4.1 & 70 & 90 \\
\hline 3 wash & 3.5 & 76 & 88 \\
\hline 4 wash & 3.2 & 81 & 84 \\
\hline 5 wash & 2.8 & 84 & 80 \\
\hline BR crystallized from MeOH & 1.9 & 86 & 75 \\
\hline BR from GPC on Sephadex G-200 & 1.2 & 92 & 86 \\
\hline
\end{tabular}

* Notes:

Percentage yield relative to BR solubilized in SDS-Na before the purification procedure.

As was shown in Table 1, $88 \%$ of phospholipids was removed by five washes (65 and $76 \%$ was removed by 1 st, 2nd and 3nd wash respectively). When the sample was solubilized in $0.1 \%(w / v)$ SDS-Na and applied to GPC on Sephadex G-200, a chromatogram shown in Figure 6 was obtained. The total endogenous phospholipids removal on the BR peak was $92 \%$ relative to the native PM. The absorbance profile shows the separated protein. For smaller BR loads $(0.1 \mathrm{mg})$, the analytical column (size) worked equally well. 


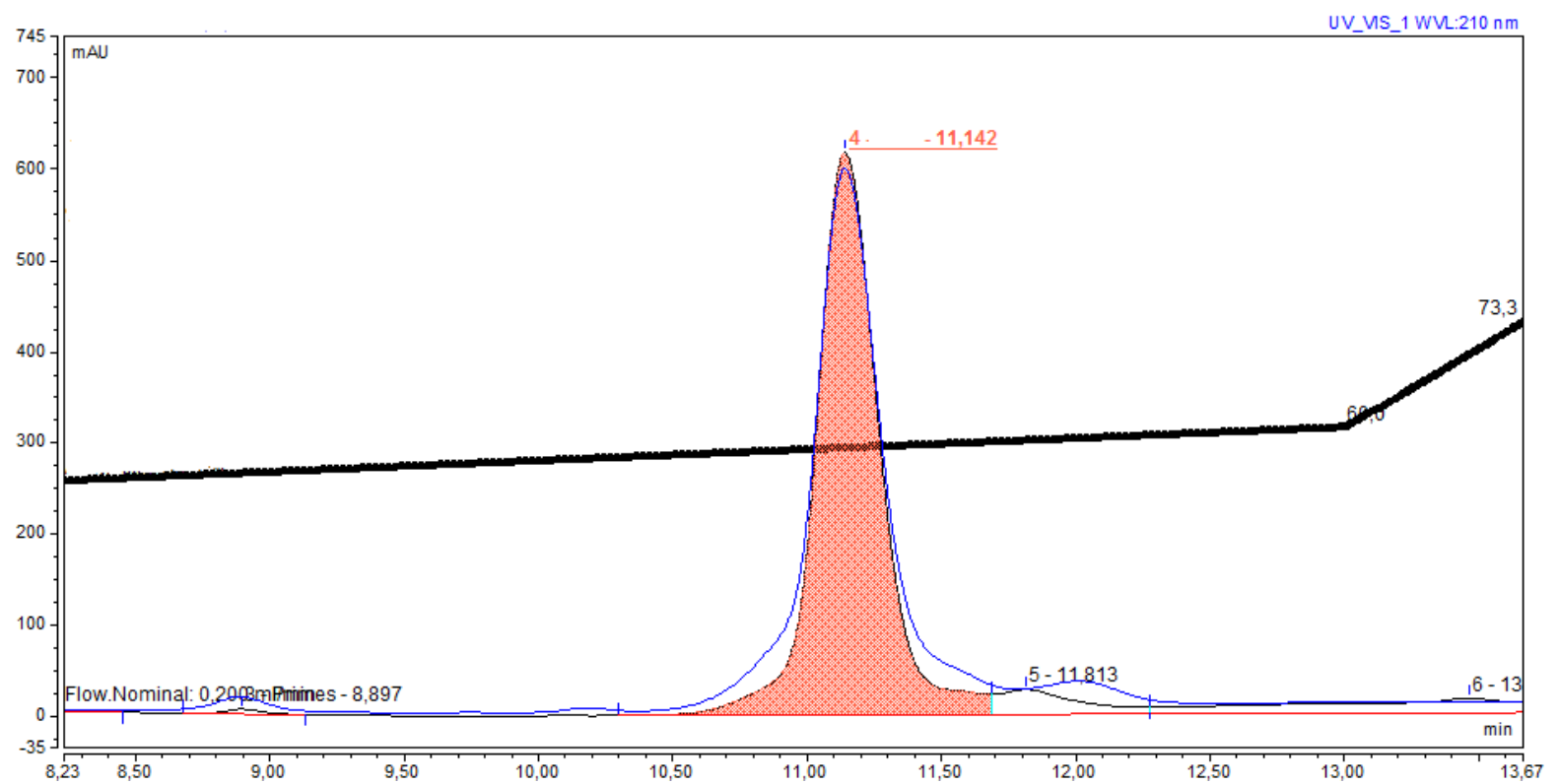

Figure 6: The GPC-chromatogram of the BR sample after purification (shaded as orange shows the separated protein): GPC (150×10 mm) column; stationary phase: Sephadex G-200 ("Pharmasia", USA) equilibrated with buffer with $0.1 \%$ (w/v) SDS-Na and 2.5 mM ETDA; specific volume: 30-40 units per $1 \mathrm{~g}$ dry Sephadex G-200; $\mathrm{t}=20 \pm 25^{\circ} \mathrm{C}$; eluent: $1 \mathrm{mM}$ Tris- $\mathrm{HCl}$ buffer $(\mathrm{pH}=7.4)$; flow rate: $10 \mathrm{ml} / \mathrm{cm}^{2} \cdot \mathrm{h}$; detection UV/VIS at $\lambda=280$ and $\lambda=568 \mathrm{~nm}$

The homogeneity of isolated BR satisfies to the requirements for reconstruction of native membranes, and was confirmed by electrophoresis in $12.5 \%$ (w/v) PAAG with $0.1 \%(\mathrm{w} / \mathrm{v})$ SDS-Na and in vitro regeneration of AP with 13-trans-retinal. The degree of regeneration of PM was determined by the ratio: $D_{\text {nat.280 }} D_{\text {nat..568 }} / \mathrm{D}_{\text {reg..280 }} \mathrm{D}_{\text {reg. } .568}\left(\mathrm{D}_{280}\right.$ and $\mathrm{D}_{568}-$ the absorbance of a suspension of native and regenerated PM at $\lambda=$ 280 and $\lambda=568 \mathrm{~nm}$ ) was $65 \mathrm{~mol} . \%$. Output of crystalline protein makes up approximately $5 \mathrm{mg}$. The isolated protein was washed with cold dist. ${ }^{2} \mathrm{H}_{2} \mathrm{O}$, centrifuged (1200 g, $15 \mathrm{~min}$ ), subjected to freeze-drying, sealed into glass ampoules and stored in frost camera at $-10^{\circ} \mathrm{C}$.

\section{Conclusions}

The technology for isolation of BR indicates high yields of the protein, as a result of which it was isolated $5 \mathrm{mg}$ of BR from $100 \mathrm{~g}$ of wet bacterial biomass. To ensure higher yields of BR it needs to accumulate more row biomass feedstock that can be easily achieved in the mass-scale laboratory conditions. The main advantage of this method is that the isolated BR retains its native configuration in combination with 13-trans-retinal, and the ability to photochemical reactions in vitro that is important for further use of BR for the construction of phototransforming nanofilms and artificial membranes containing BR.

\section{References}

Downie, J., Timucin, D.A., Smithey, D.T. \& Crew, M. (1998) Long holographic lifetimes in bacteriorhodopsin films. Optics Letters, 23(9): 730-732.

Gui-Ying, Ch., Chun-Ping, Zh., Zong-Xia, G., Jian-Guo, T., Guang-Yin, Zh. \& Qi-Wang, S. (2012) All-optical logic-gates based on bacteriorhodopsin film. Advanced Studies in Biology, 4(5): 207-216.

Hampp, N. (2000) Bacteriorhodopsin as a photochromic retinal protein for optical memories. Chem. Rev., 100: $1755-1776$.

Hampp, N. \& Oesterhelt, D. (2004) Bacteriorhodopsin and its Potential in Technical Applications. in: Nanobiotechnology / Ch. Niemeyer, C. Mirkin (eds.). Weinheim: Wiley-VCH-Verlag, 167 p.

Haupts, U., Tittor, J., Bamberg, E. \& Oesterhelt, D. (1997) General concept for ion translocation by halobacterial retinal proteins: the isomerization/switch/transfer model. Biochemistry, 36(2-7): 78-85.

Hillebrecht, J.R., Koscielecki, J.F., Wise, K.J. et al. (2005) Optimization of protein-based volumetric optical memories and associative processors by using directed evolution. Nanobiotechnology, 1: 141-151.

Jap, B.K., Maestre, M.F., Hayward, S.B. \& Glaeser, R.M. (1983) Peptide-chain secondary structure of bacteriorhodopsin. Biophys J., 43(1): 81-89.

Korposh, S.O., Sichka, M.Y., Trikur, I.I. et al. (2005) Films based on bacteriorhodopsin in sol-gel matrices. Proc. of SPIE, 5956, Paper Number 595616.

Lanyi, J.K. (2004) X-ray diffraction of bacteriorhodopsin photocycle intermediates. Molecular Membrane 
Biology, 21(3): 143-150.

Mak-Jurkauskas, M.L., Baiaj, V.S., Hornstein, M.K. et al. (2008) Energy transformations early in the bacteriorhodopsin photocycle revealed by DNP-enhanced solid-state NMR. Proc. Natl. Acad. Sci. USA, 105(3): 883-888.

Mosin, O.V., Karnaukhova, E.N. \& Pshenichnikova, A.B. (1994) Electron impact mass-spectrometry in bioanalysis of stable isotope labeled bacteriorhodopsin / 6th Intern. Conf. on Retinal proteins. Leiden: Leiden University Press, p. 115.

Mosin, O.V., Skladnev, D.A., Egorova, T.A. \& Shvets, V.I. (1996) Mass-spectrometric determination of levels of enrichment of ${ }^{2} \mathrm{H}$ and ${ }^{13} \mathrm{C}$ in molecules of amino acids of various bacterial objects. Bioorganic Chemistry, 22(10-11):856-869.

Mosin, O.V., Skladnev, D.A \& Shvets, V.I. (1999) The inclusion of deuterated aromatic amino acids in the molecule of bacteriorhodopsin Halobacterium halobium. Applied Biochemistry and Microbiology, 35(1): 34-42.

Mosin, O.V., Shvets, V.I., Skladnev, D.A. \& Ignatov, I. (2012) Synthesis of $\left[{ }^{2}\right.$ H]bacteriorhodopsin labeled by deuterium on residues of aromatic amino acids. Khimicheskaya Technologiya (Chemical Engineering), Publishing House "Nauka \& Technology" Moscow, 9: 553-564.

Mosin, O.V., Shvets, V.I., Skladnev, D.A. \& Ignatov, I. (2013) Biosynthesis of trans-membrain phototransforming protein $\left[{ }^{2} \mathrm{H}\right]$ bacteriorhodopsin, labeled with deuterium on residues of aromatic amino acids $\left[2,3,4,5,6-{ }^{2} \mathrm{H}_{5}\right]$ Phe, $\left[3,5-{ }^{2} \mathrm{H}_{2}\right] \mathrm{Tyr}$ and $\left[2,4,5,6,7-{ }^{2} \mathrm{H}_{5}\right] \mathrm{Trp}$. Problems of Biological, Medical and Pharmaceutical Chemistry, 8: 29-39.

Mohammadi, S. (2012) Bacteriorhodopsin based films in a nanomemory. Advanced Studies in Biology, 4(5): 207-216.

Nonella, M., Windemuth, A. \& Schulten, K. (1991) Structure of Bacteriorhodopsin and in situ isomerization of retinal: a molecular dynamics study. Journa Photochem. Photobiol., 54(6): 937-948.

Oesterhelt, D. \& Stoeckenius, W. (1971) Rhodopsin - like protein from the purple membrane of Halobacterium halobium. Nature, 233(89): 49-160.

Oesterhelt, D. (1988) The Structure and Mechanism of the Family of Retinal Proteins from Halophilic Archaea Curr. Op. Struct. Biol., 8: 489-500.

Rudiger, M., Tittor, J., Gerwert, K. \& Oesterhelt D. (1997) Reconstitution of bacteriorhodopsin from the apoprotein and retinal studied by Fourier-transformed infrared spectroscopy. Biochemistry, 36: 48674874.

Seitz, A. \& Hampp, N. (2000) Kinetic optimization of bacteriorhodopsin films for holographic interferometry. $J$. Phys. Chem. B., 104(30): 7183-7192.

Shamansky, L.M., Minh Luong, K., Han, D. \& Chronister, E.L. (2002) Photoinduced kinetics of bacteriorhodopsin in a dried xerogel glass. Biosensors \& Bioelectronics, 17: 227-231.

Shuguang, W.U., Ellerby, L.M., Cohan, J.S. et al. (1993) Bacteriorhodopsin rncapsulated in transparent sol-gel glass: a new biomaterial. Chem. Mater, 5: 115-120.

Vought, B.W. \& Birge, R.R. (Eds.) (1999) Molecular Electronics and Hybrid Computers / In: Wiley Encyclopedia of Electrical and Electronics Engineering. NY: Wiley-Interscience, 490 p.

Wang, W.W., Knopf, G.K. \& Bassi, A.S. (2008) Bioelectronic imaging array based on bacteriorhodopsin film. IEEE Transactions on Nanobioscience, 7(4): 249-56.

Weetall, H. (1996) Retention of bacteriorhodopsin activity in dried sol-gel glass. Biosensors \& Bioelectronics, 11: 325-333.

Zimanyi, L., Cao, Y., Needleman, R., Ottolenghi, M. \& Lanyi, J.K. (1993) Pathway of proton uptake in the bacteriorhodopsin photocycle. Biochemistry, 32: 7669-7678. 
The IISTE is a pioneer in the Open-Access hosting service and academic event management. The aim of the firm is Accelerating Global Knowledge Sharing.

More information about the firm can be found on the homepage:

http://www.iiste.org

\section{CALL FOR JOURNAL PAPERS}

There are more than 30 peer-reviewed academic journals hosted under the hosting platform.

Prospective authors of journals can find the submission instruction on the following page: http://www.iiste.org/journals/ All the journals articles are available online to the readers all over the world without financial, legal, or technical barriers other than those inseparable from gaining access to the internet itself. Paper version of the journals is also available upon request of readers and authors.

\section{MORE RESOURCES}

Book publication information: http://www.iiste.org/book/

Academic conference: http://www.iiste.org/conference/upcoming-conferences-call-for-paper/

\section{IISTE Knowledge Sharing Partners}

EBSCO, Index Copernicus, Ulrich's Periodicals Directory, JournalTOCS, PKP Open Archives Harvester, Bielefeld Academic Search Engine, Elektronische Zeitschriftenbibliothek EZB, Open J-Gate, OCLC WorldCat, Universe Digtial Library, NewJour, Google Scholar

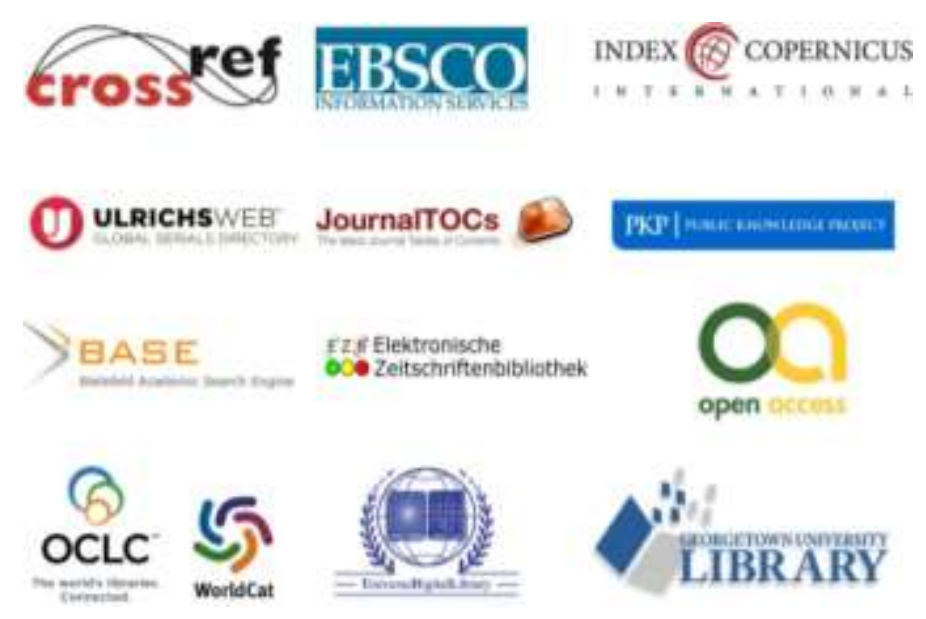

